\title{
Cellular vehicles based on neutrophils enables targeting of atherosclerosis
}

Yanan $\mathrm{Xue}^{\dagger}$, Yue Wu${ }^{\dagger}$, Qianqian Wang ${ }^{\dagger}$, Lingjing Xue ${ }^{\dagger}$, Zhigui Su${ }^{*}, \dagger$, Can Zhang ${ }^{*}{ }^{\dagger}$

†State Key Laboratory of Natural Medicines

Jiangsu Key Laboratory of Drug Discovery for Metabolic Diseases

Center of Advanced Pharmaceuticals and Biomaterials

China Pharmaceutical University, No. 24 Tongjiaxiang, Nanjing, 210009, China

* Corresponding author at:

State Key Laboratory of Natural Medicines

Jiangsu Key Laboratory of Drug Discovery for Metabolic Diseases

Center of Advanced Pharmaceuticals and Biomaterials

China Pharmaceutical University

24 Tong Jia Xiang

Nanjing, China 210009

Phone /Fax: +862583271076

Email: zhiguisu707@cpu.edu.cn (Zhigui Su); zhangcan@cpu.edu.cn (Can Zhang) 
1. Synthesis of cationic lipid, 1,5 -dioctadecyl- $N$-histidyl-L-glutamate $\left(\mathrm{HG}_{2} \mathrm{C}_{18}\right)$ 

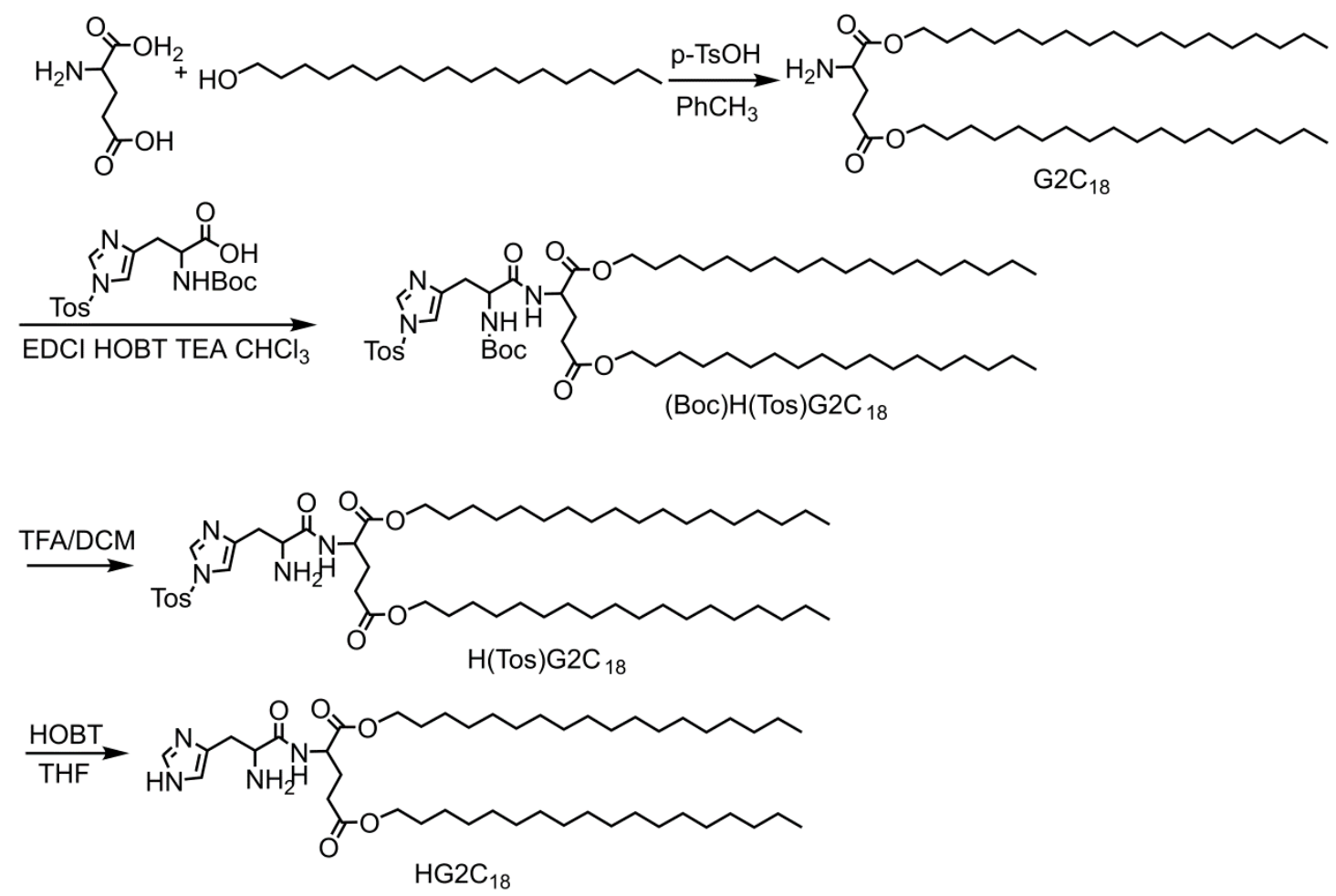

Scheme 1. Synthesis route of $\mathrm{HG} 2 \mathrm{C}_{18}$

L-glutamic acid (11.8 g, $80.2 \mathrm{mmol})$ and $p$-toluenesulfonic acid ( $p$-TsOH, $18.3 \mathrm{~g}$, $96.2 \mathrm{mmol})$ were dissolved in toluene $(400 \mathrm{~mL})$ with stirring for $1 \mathrm{~h}$. Next, octadecanol (47.8 g, $176.7 \mathrm{~mol})$ was added with stirring for $12 \mathrm{~h}$. After removing toluene by the rotary evaporation, the residue was dissolved in chloroform $(300 \mathrm{~mL})$, followed by washing with saturated $\mathrm{NaHCO}_{3}$ solution $(300 \mathrm{~mL} \times 2)$ and brine $(300$ $\mathrm{mL} \times 1$ ). The organic layer was dried over anhydrous $\mathrm{Na}_{2} \mathrm{SO}_{4}$, filtered and concentrated. 1,5-Dioctadecyl-L-glutamate $\left(\mathrm{G}_{2} \mathrm{C}_{18}, 29.0 \mathrm{~g}\right)$ was recrystallized from methanol $(300 \mathrm{~mL})$ with a yield of $55.4 \%$.

Boc-L-His(Tos)-OH (2.28 g, $5.6 \mathrm{mmol})$, EDCI (1.71 g, $8.9 \mathrm{mmol})$ and NHS (1.02 g, $8.9 \mathrm{mmol})$ were dissolved in chloroform $(100 \mathrm{~mL})$ with stirring for $3 \mathrm{~h}$ at room temperature. The synthesized $\mathrm{G}_{2} \mathrm{C}_{18}(3.56 \mathrm{~g}, 5.6 \mathrm{mmol})$ and triethylamine (TEA, 2.3 $\mathrm{mL}, 16.7 \mathrm{mmol})$ were dissolved in chloroform $(50 \mathrm{~mL})$ with stirring for $1 \mathrm{~h}$ at room temperature. Afterward, two solutions mentioned above were mixed together with further stirring for $12 \mathrm{~h}$ at room temperature. The reaction was washed with water $(100 \mathrm{~mL} \times 2), 10 \%$ citric acid solution $(100 \mathrm{~mL} \times 2)$ and brine $(100 \mathrm{~mL} \times 1)$ successively and dried over anhydrous $\mathrm{Na}_{2} \mathrm{SO}_{4}$, filtered and concentrated. Upon recrystallization from methanol $(50 \mathrm{~mL})$, a white powder ((Boc)H(Tos) $\left.\mathrm{G}_{2} \mathrm{C}_{18}, 3.99 \mathrm{~g}\right)$ 
was obtained with a yield of $68.3 \%$.

The obtained (Boc) $\mathrm{H}(\mathrm{Tos}) \mathrm{G}_{2} \mathrm{C}_{18}$ (3.99 $\mathrm{g}, 3.8 \mathrm{mmol}$ ) was dissolved in 50\% solution of trifluoroacetic acid (TFA) $(60 \mathrm{~mL})$ with stirring for $6 \mathrm{~h}$ at room temperature. The $\mathrm{pH}$ of the reaction mixture was then adjusted to 8-9 with saturated $\mathrm{NaHCO}_{3}$ solution and the organic layer was washed with water $(100 \mathrm{~mL} \times 1)$ and brine $(100 \mathrm{~mL} \times 1)$. After dried over anhydrous $\mathrm{Na}_{2} \mathrm{SO}_{4}$ and concentrated, 1,5-dioctadecyl $\mathrm{N}$-( $\mathrm{N}$-g-tosyl) histidyl-L-glutamate $\left(\mathrm{H}(\mathrm{Tos}) \mathrm{G}_{2} \mathrm{C}_{18}, 3.31 \mathrm{~g}\right)$ was obtained with a yield of $93.2 \%$.

$\mathrm{H}(\mathrm{Tos}) \mathrm{G}_{2} \mathrm{C}_{18}(3.31 \mathrm{~g}, 3.5 \mathrm{mmol})$ and HOBt $(5.68 \mathrm{~g}, 42.0 \mathrm{mmol})$ were dissolved in tetrahydrofuran $(100 \mathrm{~mL})$ with stirring for $6 \mathrm{~h}$ at $40{ }^{\circ} \mathrm{C}$. The reaction was evaporated and 1,5-dioctadecyl- $N$-histidyl-L-glutamate $\left(\mathrm{HG}_{2} \mathrm{C}_{18}, 1.71 \mathrm{~g}\right)$ was obtained with a yield of $62.0 \%$ by silica gel column chromatography separation (dichloromethane:methanol, 15:1, v:v).

$\mathrm{HG}_{2} \mathrm{C}_{18}:{ }^{1} \mathrm{H}$ NMR $\left(300 \mathrm{MHz}, \mathrm{CDCl}_{3}\right) \delta: 7.16(\mathrm{~d}, 1 \mathrm{H}, \mathrm{N}=\mathrm{CH}), 6.94(\mathrm{~d}, 1 \mathrm{H}$, $\left.\mathrm{CH}_{2} \mathrm{C}=\mathrm{CH}\right), 4.50(\mathrm{q}, 1 \mathrm{H}, \mathrm{NHCH}), 4.12-4.05\left(\mathrm{~m}, 4 \mathrm{H}, \mathrm{COOCH}_{2}\right), 3.88(\mathrm{~m}, 1 \mathrm{H}$, $\mathrm{NH}_{2} \mathrm{CH}$ ), 3.10-2.93 (q, 2H, $\mathrm{NH}_{2} \mathrm{CHCH}_{2}$ ), 2.37 (t, 2H, $\mathrm{CH}_{2} \mathrm{CO}$ ), 2.18-1.98 (m, 2H, $\left.\mathrm{NHCHCH}_{2}\right), 1.62-1.25\left(\mathrm{~m}, 64 \mathrm{H}, \mathrm{CH}_{2}\right.$ (stearyl)), 0.88 (t, 6H, $\left.\mathrm{CH}_{2} \mathrm{CH}_{3}\right) . \mathrm{MS}$ (ESI): $(\mathrm{M}+\mathrm{H})^{+}$calcd. for $\mathrm{C}_{47} \mathrm{H}_{89} \mathrm{~N}_{4} \mathrm{O} 5,789.7$; found, 789.7 .

\section{The cytotoxicity study of C6-CL on NEs}

The citotoxicity of C6-CL on NEs was evaluated by the MTT method. $10^{4}$ of NEs in RPMI 1640 was placed into 96 well plates and incubated for $1 \mathrm{~h}$ at $37^{\circ} \mathrm{C}$ with $5 \%$ $\mathrm{CO}_{2}$. Then, the RPMI 1640 was substituted with different concentration of C6-CL diluted with RPMI 1640. After $8 \mathrm{~h}, 10 \mu \mathrm{L}$ of MTT solution $(5 \mathrm{mg} / \mathrm{mL})$ was added into each well and NEs were further incubated for $4 \mathrm{~h}$. After incubation, the supernatant in each well was withdrawn and $200 \mu \mathrm{L}$ of DMSO was added to dissolve the blue formazan crystals in NEs. The absorbance in each well was measured at $570 \mathrm{~nm}$. The viability percentage was calculated by the following formula:

$$
\text { cell viability }(\%)=A_{s} / A_{p} \times 100 \%
$$


where $A_{s}$ was absorbance value of each sample well and $A_{p}$ was the absorbance value of positive-control wells without treated by C6-CL.

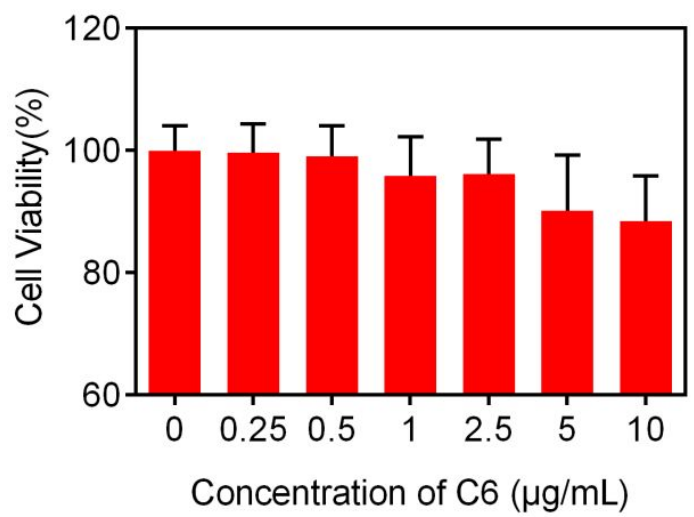

Figure S1. In vitro cytotoxicity of C6-CL against NEs as a function of C6 concentration after $8 \mathrm{~h}(\mathrm{n}=5)$.
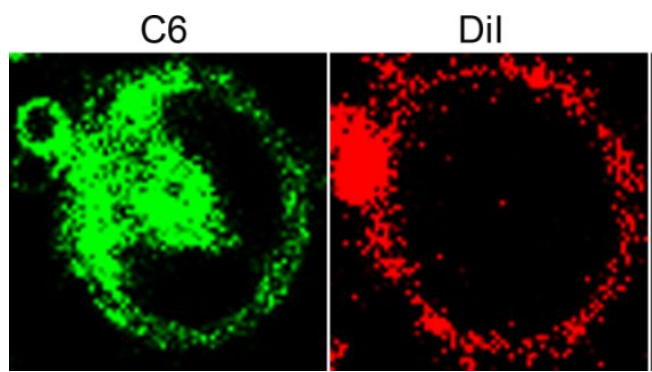

Heochst3334

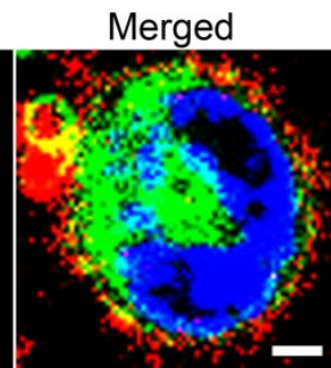

Figure S2. The CLSM image for double-labelled C6-CL/DiI-NEs. Scale bar $=2 \mu \mathrm{m}$.

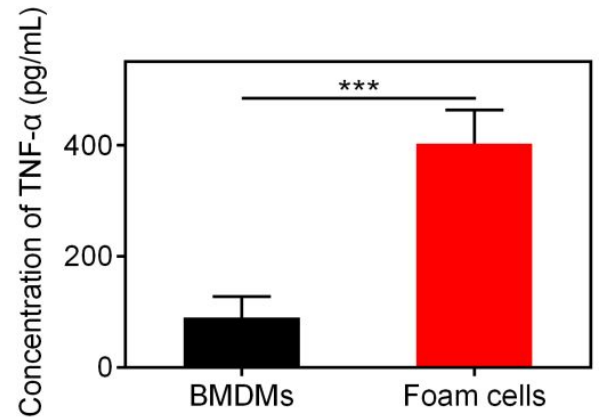

Figure S3. The expression of TNF- $\alpha$ in supernatant of BMDMs and foam cells $(\mathrm{n}=$ $3)$. 


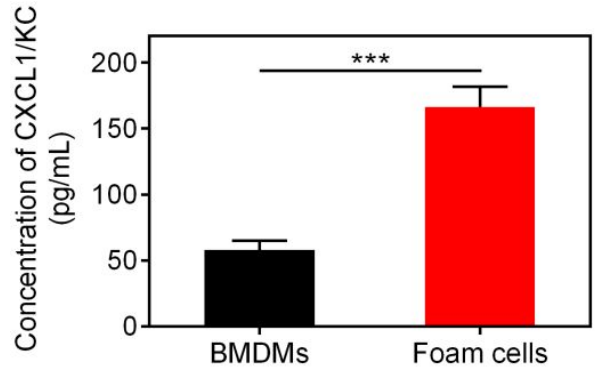

Figure S4. The expression of CXCL1/KC in supernatant of BMDMs and foam cells $(\mathrm{n}=3)$.
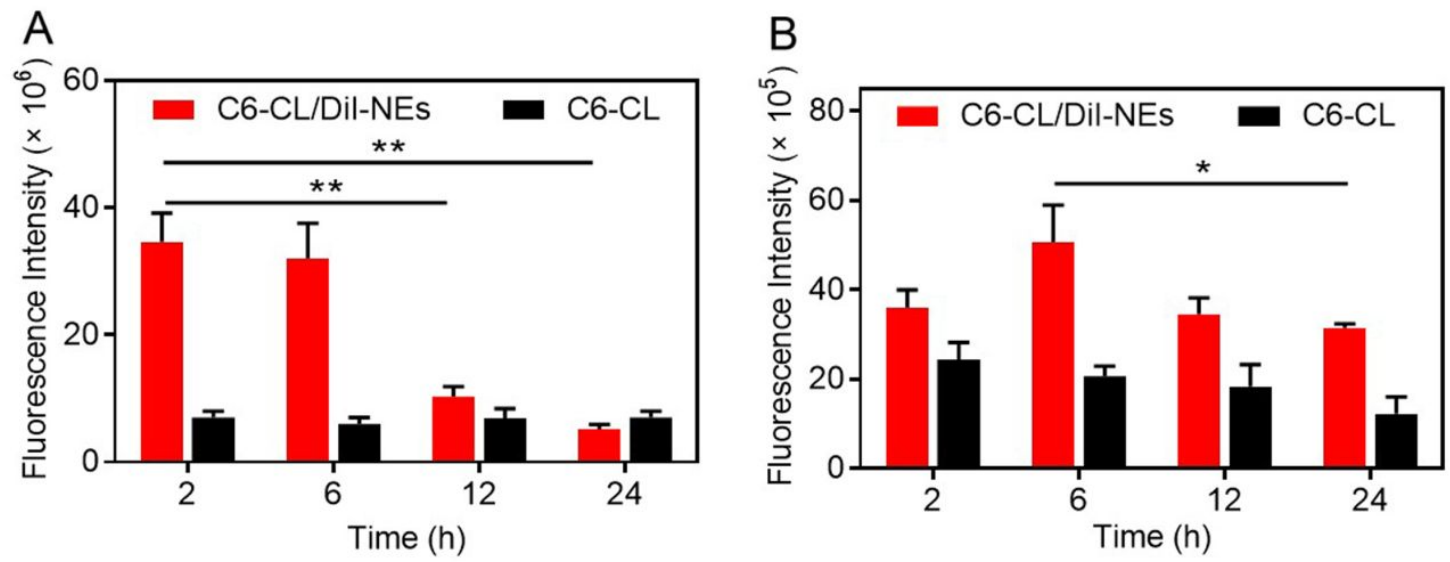

Figure S5. The blood fluorescent intensity-time curve after intravenous administration with C6-CL/DiI-NEs or C6-CL for different times $(\mathrm{n}=3)$.

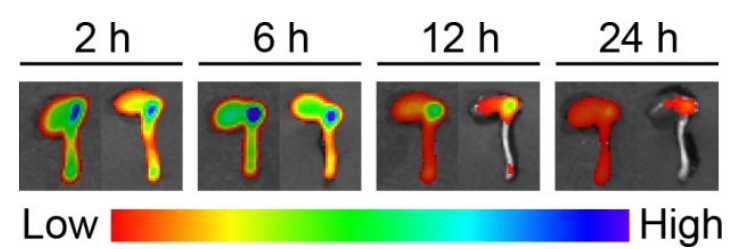

Figure S6. The ex vivo fluorescent images of heart with aortas after intravenous administration with DiD-CL/NEs for different times $(n=2)$. 


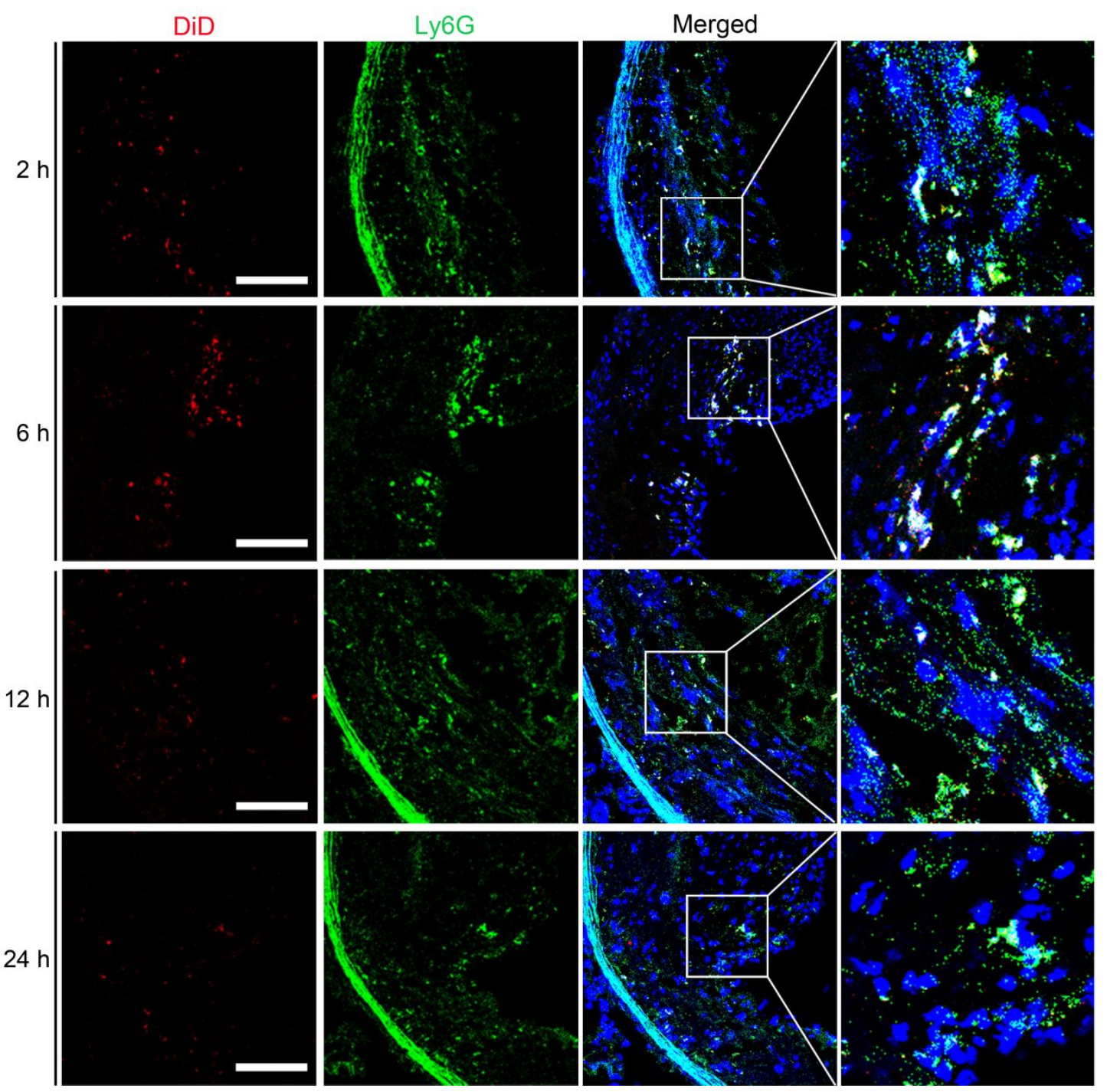

Figure S7. The cryostat section of aortic root with atherosclerotic plaque from ApoE ${ }^{-/-}$mice after intravenously administered with DiD-CL/NEs. The slides were stained with DAPI. The fluorescent images: red $=$ DiD of DiD-CL/NEs, blue $=$ nucleus, green $=$ anti-Ly6G-FITC. Scale bar $=200 \mu \mathrm{m}$. 


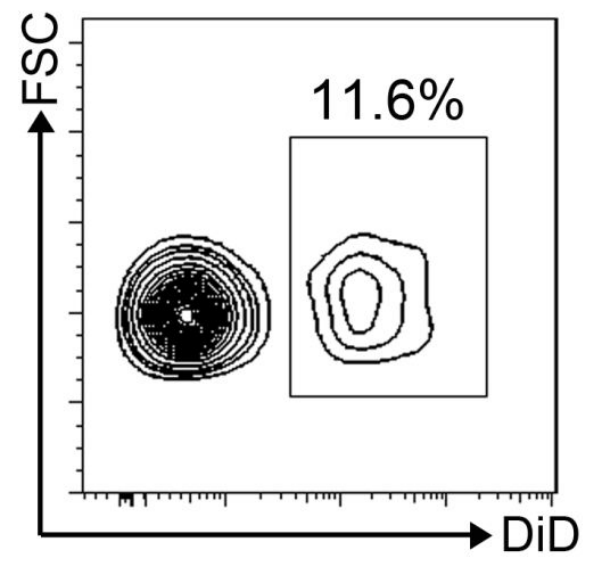

Figure S8. Representative flow cytometry plots showing the percentages of DiD-CL/NEs to total of NEs in the aorta. 